\title{
Does Environmental Information Disclosure Affect the Sustainable Development of Enterprises: The Role of Green Innovation
}

\author{
Dameng Hu, Yuanzhe Huang * and Changbiao Zhong
}

check for updates

Citation: Hu, D.; Huang, Y.; Zhong, C. Does Environmental Information Disclosure Affect the Sustainable Development of Enterprises: The Role of Green Innovation. Sustainability 2021, 13, 11064. https://doi.org/ $10.3390 /$ su131911064

Academic Editor: Luigi Aldieri

Received: 2 September 2021

Accepted: 5 October 2021

Published: 7 October 2021

Publisher's Note: MDPI stays neutral with regard to jurisdictional claims in published maps and institutional affiliations.

Copyright: (c) 2021 by the authors. Licensee MDPI, Basel, Switzerland. This article is an open access article distributed under the terms and conditions of the Creative Commons Attribution (CC BY) license (https:// creativecommons.org/licenses/by/ $4.0 /)$.
School of Business, Ningbo University, Ningbo 315211, China; hdm8272096@outlook.com (D.H.); zhongchangbiao@nbu.edu.cn (C.Z.)

* Correspondence: huangyuanzhe@nbu.edu.cn

\begin{abstract}
Along with command-and-control and market-incentive environmental regulation policies, environmental information disclosure (EID) is an important measure used by the Chinese government to implement environmental governance. In the context of advocating for corporate sustainable development and green governance, this study uses data from China's Shanghai and Shenzhen A-share listed companies in heavily polluting industries spanning 2008-2019 to empirically explore the relationship between corporate EID and green innovation (GI). The results reveal the following: (1) high-quality EID significantly promotes the absolute GI level and the relative GI level of enterprises. (2) An intermediary model found that the internal mechanism of corporate EID used to promote GI mainly comes from the government's energy-saving innovation subsidy effect and the social media attention effect. (3) Corporate EID has a more evident promotional effect on green patents for energy conservation and green patents for inventions. (4) The EID of state-owned enterprises is more conducive to GI than to the activities of private enterprises. (5) The EID of enterprises in high-level administrative cities has no significant impact on GI. However, it has a significant promoting effect in low-level administrative cities. The research not only provides an empirical basis for China to improve the environmental information disclosure system of listed companies but also to offer guidance for companies to pursue green and sustainable development.
\end{abstract}

Keywords: environment information disclosure; sustainable development; absolute green innovation; relative green innovation; heavily polluting industries

\section{Introduction}

Over the past 40 years of reform and opening up in China, the consumption of fossil fuel and pollution due to emissions have increased sharply with rapid economic development. Such a situation undoubtedly poses a serious threat to the ecological environment. Therefore, the ability to effectively control the emissions of polluting enterprises and to realize a green transformation is of great significance to improving China's environmental quality and to promoting sustainable economic development. In recent years, the Chinese government has implemented a series of environmental regulatory measures to alleviate increasingly serious environmental problems, such as promoting the transformation of and upgrading the energy structure, controlling the intensity of energy consumption, and implementing carbon emissions trading [1-3]. At present, China's environmental governance has entered a new stage. Following the implementation of command-and-control and market-incentive environmental regulations, environmental information disclosure (EID) has been an effective means to reduce information asymmetry between enterprises and the public. EID is another important measure that the Chinese government implements to promote environmental governance [4].

By improving the public's access to environmental pollution information and by allowing the public to participate in environmental governance actions, EID is an important way for enterprises to convey their environmental protection awareness and responsibility to the government and the public $[5,6]$. Since the 1970s, developed economies, led by the 
United States, have required enterprises to disclose their environment-related activities and information to the public [7,8]. Related EID policies have become an important supplements or alternatives to the government's direct environmental control and market tools. Certain measures, such as the TRI (Hazardous Substance Emission Inventory) project, aim to strengthen the public's supervision of corporate emissions by providing the public with information on corporate chemical and hazardous substance emissions. China's EID policy was launched at the end of the 20th century and has been gradually implemented and developed. In 2008, the Ministry of Environmental Protection issued the Measures on Environmental Information Disclosure (Trial), which required environmental protection departments at all levels to disclose their total emission index of environmental pollutants, and provided a list of serious polluters from 1 May 2008. In the same year, the China Securities Regulatory Commission began requiring listed companies to submit environmental impact assessment reports. Then, the Ministry of Environmental Protection issued the Measures for Supervisory Monitoring and Information Disclosure of Pollution Sources of Key State Monitored Enterprises in July 2013, which required environmental protection departments at all levels to disclose monitoring information from the sources of pollution from key national monitoring companies.

At present, studies on EID mainly include the following three aspects: first, researchers have delved into the specific measures of $\operatorname{EID}[9,10]$, focused on the quantity and quality of environmental disclosure. The number of EIDs is represented by the number of pages or lines in the annual report involved in environmental disclosure [11]. Meanwhile, the quality of EID is obtained by scoring the information disclosed in the annual report [12]. Second, scholars have examined the driving force of EID. Internal factors mainly refer to enterprise characteristics [13], such as enterprise size, ownership, and industry type [14]. External factors mainly refer to the pressure of stakeholders, such as external supervision, institutional elements, and social organizations [15]. Third, from a micro-perspective, the authors of related literature have investigated the impact of EID on corporate financial performance [16-19], corporate risk [20], environmental performance [21-23], location choice [24], and innovation [25]. Whether environmental regulation policies can induce innovation has always been a hot topic of research, and their views are not uniform. Some scholars believe that environmental regulation has an inhibitory effect on innovation by adding additional burdens to enterprises. This view is described as the compliance cost theory [26,27]. However, according to the Porter hypothesis [28], flexible and reasonable environmental regulations do not cause many obstacles to business operations and effectively stimulate the enterprise's willingness to innovate and to improve its innovation performance.

According to the biased technological progress theory [29], innovation itself and its results are multi-directional. Clean innovation may improve environmental quality [30], and pollution innovation may worsen the ecological environment [31,32]. This dual engagement indicates that even if the Porter hypothesis [28] is established, the positive impact of environmental regulation on innovation may not have effects on the energy environment. For this reason, Rhodes and Wield [33] first proposed the concept of green innovation (GI), which can be defined as the processes, technologies, and products that can reduce the consumption of energy and raw materials in addition to environmental pollution, and can promote sustainable development [34]. Compared with general enterprise innovation, GI can help enterprises achieve win-win economic and environmental benefits. In addition, it is an important way to mitigate the adverse impact of economic activities on the environment [35]. The existing literature mainly studies the effect of command-and-control and market-motivated environmental regulations on GI [36,37], and few scholars paid attention to the relationship between EID and enterprise GI. However, whether the policy effectiveness of EID as a gradually emerging voluntary environmental regulation mode can be reflected in inducing GI of enterprises to unify economic benefits and environmental benefits is worth further study. Furthermore, what is the possible mechanism of action? These problems provide space for this paper to explore the impact of EID on enterprise GI and its internal mechanism. 
In order to solve the above problems, this paper selects China, which is currently vigorously promoting EID policy, as the object of policy effect evaluation. As major consumers of natural resources and pollutant emission sources, China's heavily polluting enterprises are important subjects and key actors in green governance [38]. On this basis, this study uses data sets of heavily polluting industries among listed companies in China and conducts a content analysis. Then, this research aims to design an EID index and to provide a quantitative evaluation of the level of EID and enterprise. The study uses the patent information of listed companies and the international patent classification green list to determine an enterprise's absolute and relative GI levels. Moreover, the research analyzes the impact of enterprise EID on GI. The results reveal that the improvement in enterprise EID significantly promotes its GI ability. Moreover, the results are still robust after replacing the dependent and independent variables, adding city-level control variables, and dividing the different growth periods of EID. The intermediation effect test also finds that the internal mechanism of EID used to promote enterprise GI mainly includes two aspects: government subsidies for energy-saving innovation, and social media attention.

Our research provides four contributions. First, previous studies have mostly focused on the evaluation of the policy effects of command-and-control and market-incentive environmental regulations [39,40], while this article starts with voluntary environmental regulation EID to examine the actual impact of unique policy guidance on micro-enterprise innovation. Another way of thinking is provided for enterprises to achieve green and sustainable development. Second, this paper analyzes and empirically examines the internal mechanism of the impact of EID on corporate GI from the three levels of government, society, and enterprises, and finds that its channels mainly come from the government-level energy-saving innovation subsidy effect and the social-level media attention effect, which extends the chain of the impact of EID on corporate GI and makes relevant theories and literature more complete and reasonable. Third, this study conducts a more detailed analysis of heterogeneity in terms of patent categories, corporate ownership, and the administrative hierarchy of the city to which the company belongs. Many of our conclusions provide certain significant and practical guidance for different cities and companies. Fourth, using the international patent classification green list and the item-by-item segmentation extraction method, the absolute GI level and relative GI level indicators are constructed, which provide the possibility of accurately measuring the GI level of enterprises from the micro level. Additionally, combined with the practice of China's environmental supervision in recent years, an environmental information disclosure index system, including 5 first-level indicators and 26 second-level indicators, has been redesigned to quantitatively evaluate the EID level of enterprises.

The rest of paper is organized as follows. Section 2 describes the related theories and develops hypotheses. Section 3 presents research models. Section 4 provides the empirical results. Section 5 shows the results of heterogeneity analysis. Section 6 includes the discussions, policy implications, and research limitations.

\section{Theoretical Analysis and Research Hypotheses}

\subsection{EID and Corporate GI}

In the modern business environment, companies not only encounter suppression by competitors but also face rejection from consumers, governments, and other recipients. Therefore, in the context of the Internet, an enterprise's active acquisition of organizational legitimacy in the course of its operations is conducive to its adaptation to a new operating environment. Organizational legitimacy is one of the core concepts of organizational sociology. With the strengthening of the interdisciplinary and continuous in-depth study of business management theory, this concept is being widely used in business organization research. According to the theory of the organizational legitimacy of enterprises, companies must abide by certain social norms in their business activities and must actively assume social responsibilities; moreover, the act of disclosing environmental information can prove the legitimacy of a company's existence [41,42]. Under the pressure of strict and complete 
environmental laws and regulations, companies tend to disclose more detailed environmental protection measures and pollution discharge information to obtain government support and to avoid the risk of violations $[43,44]$. To cope with the resulting pressures from the government and public supervision, pollution-intensive enterprises must continuously innovate their production processes, production technologies, and commodity use to improve their own pollution-control capabilities [45].

At the same time, the development of a company cannot be separated from the input or participation of its stakeholders. Enterprises should be responsible not only for shareholders but also for the stakeholders who have various economic or non-economic interests with the company, which constitutes the stakeholder theory. The company pursues the overall interests of stakeholders, and business decision-making must consider these stakeholders' interests or accept their constraints [46]. As environmental degradation and pollution intensify, stakeholders pay increased attention to the environmental responsibility of enterprises [47]. Hence, companies need to respond to the pressure of stakeholders to attract stakeholders who are concerned about environmental responsibility, environmental policies, and environmental risks, and gain a competitive advantage in the future. Subsequently, companies selectively disclose relevant environmental information [48] to create a good green image [49]. Most investors pay much attention to the sustainable development of enterprises, and are more willing to invest in enterprises with higher levels of environmental disclosure [50]. Such attention further accelerates the innovation of corresponding environmentally friendly products and green processes.

In the choice of corporate strategic behavior, in order to overcome the adverse selection and moral hazard caused by information asymmetry, the signaling theory is undoubtedly important. Enterprise insiders usually have more corporate information than outsiders. They send signals to the market and outsiders through observable behaviors and appropriate mechanisms so that outsiders can understand the true situation within the company and can make reasonable decisions, helping the company to obtain good developmental opportunities. At the same time, in order to avoid being suspicious or distrusted by investors, companies also have a strong motivation to transmit internal signals that are not available to outsiders. The disclosure of environmental information by companies is a signal for investment and product markets to actively perform environmental responsibilities. On the one hand, the asymmetry of the signal is weakened, which reduces investment risk for investors, promotes corporate financing [51], and provides financial support for corporate GI. On the other hand, the high-quality environmental information disclosed by companies also attracts environmentally sensitive consumer groups [52]. Increasing attention has also spawned a demand for corresponding environmentally friendly products and green technologies, which, in turn, can encourage companies to optimize production processes, improve production processes, increase R\&D and the production of environmentally friendly products, and bring more GI [53,54].

In addition, enterprises are in fierce competition all the time. EID is undoubtedly a kind of self-regulation and self-discipline. It actively seeks various pressures from the government, competitors, and customers; accumulates environmental protection experience and technology; and forms the efficient environmental management of the enterprise. Moreover, it has the ability [55] to promote enterprises to improve resource use efficiency, to conduct $R \& D$ and innovation, and to reduce pollution emissions. On the basis of the above analysis, we propose the hypotheses below.

\section{Hypothesis 1 (H1). EID promotes the GI of enterprises.}

\subsection{Government Level: Energy-Saving Innovation Subsidy Effect}

For local governments, the problem of environmental pollution has become increasingly serious, and environmental protection has become the primary political goal. The government focuses on whether enterprises, especially heavy-polluting enterprises that are the main sources of pollution, cooperate with the government's environmental pro- 
tection work. Moreover, the government regards heavily polluting companies actively disclosing high-quality environmental information as active supporters of environmental protection policies. Thus, such support helps the government grasp the progress of real-time environmental protection work and strengthen its control over heavily polluting companies. The government's move to strengthen its control over corporate environmental protection requires it to use its own resources in exchange. The government's subsidies for high-quality environmental disclosures related to energy conservation and environmental protection innovations are an important part of the government's bargaining chips. At the same time, corporate GI requires long-term investment of a large amount of resources and funds. Moreover, insufficient resource constraints and incentives are the primary problems that plague corporate GI [56]. The government's corresponding energy-saving innovation subsidies provide financial incentives for enterprises' GI, alleviate the resource constraints of enterprises, and reduce the cost of GI [57]. These subsidies are also conducive to alleviating managers' concerns about the uncertainty of GI activities and to enhancing the enterprise's ex ante tolerance of GI risks [58]. Therefore, under the effect of the resource compensation that the government provides for high-quality environmental disclosure companies, companies have the ability to increase R\&D activities for GI. On the basis of the above analysis, we propose the following hypothesis:

Hypothesis 2 (H2). EID promotes corporate GI by increasing government subsidies for energysaving innovation.

\subsection{Social Level: Media Attention Effect}

From a social point of view, the media shoulders the responsibility of disseminating corporate information, and the process of information collection, processing, and dissemination is conducive to increasing the amount of information that stakeholders can obtain, which, in turn, influences the decision making of stakeholders [59]. With the development of information technology and the popularization of the Internet, the intermediary role of the media as providers of information in the capital market has become increasingly critical [60]. Corporate environmental protection measures and pollution emissions are hot topics reported as news by the media as well as important content to which governments, banks, and investors pay attention. By disclosing high-quality environmental information, companies differentiate themselves from companies with weak environmental awareness and attract more media attention. Through the signal transmission function of the media, companies with excellent environmental performance are frequently exposed to the public, which undoubtedly improves the company's social reputation [18]. Thus, this enhancement attracts additional stakeholders in the capital market [61]. As an audience of the media, consumers also increase their demand for green products. This demand puts companies under public pressure, thus compelling them to fulfill their environmental responsibilities and act to protect the environment. Therefore, enterprises attract media attention through high-quality EID, and extensive media reports have allowed enterprises to gain the favor of investors and consumers. In turn, the public pressure that such favors generate prompts enterprises to increase their GI activities. On the basis of the above analysis, we propose the following hypothesis:

Hypothesis 3 (H3). EID promotes corporate GI by increasing social media attention.

\subsection{Enterprise Level: Cost Effect of Debt Financing}

Enterprises require diverse resources and a certain market position to carry out R\&D and innovation activities, especially GI activities that need longer return periods; moreover, this requirement is inseparable from the continuous investment of R\&D capital [62]. Debt and equity financing are important sources of corporate funds. Therefore, the key to affecting corporate GI activities lies in whether EID can reduce corporate financing costs. In China, borrowing from banks is still an important way for enterprises to raise funds 
given the high threshold of equity financing and the long application period under the background of relatively scarce liquid equity funds. The introduction of China's green credit policy and its subsequent rapid development have strictly restricted bank loans to heavily polluting companies [63]. Efficient and transparent EID helps heavily polluting companies secure green credit [15] and, at the same time, helps them obtain this credit at lower interest rates through bank loans [64]. In addition, companies actively disclosing high-quality EID can reduce non-dispersible estimated risks for investors and improve the evaluation level of external stakeholders on the company through the incremental effects of disseminating information, which is conducive to the creditors' estimation of the debtors' solvency and reduces creditors' level of demand for borrowing, thereby reducing the debt financing cost of the enterprise [65]. Therefore, the company itself can reduce the debt financing cost of banks or other creditors to the company by disclosing high-quality EID. Thus, it can provide financial support for GI. On the basis of the above analysis, we propose the following hypothesis:

Hypothesis 4 (H4). EID promotes corporate GI by reducing corporate debt financing costs.

\section{Research Design}

\subsection{Data Sources}

Judging from the actual situation of China's domestic EID, listed companies in heavily polluting industries are more concerned about their environmental behavior because such behavior is not only related to the survival and development of these companies but also linked to the effectiveness of national environmental supervision. According to the Listed Companies' Environmental Inspection Industry Classification Management Directory issued by the General Office of the Ministry of Environmental Protection of China in 2008 and the Listed Companies Industry Classification Guidelines issued by the China Securities Regulatory Commission in 2012, this article selects China's Shanghai and Shenzhen Ashare companies listed as polluting industries from 2008 to 2019 as research samples. The enterprise-level data came from the CSMAR and CNRDS databases. The CSMAR database provided this article with a wealth of basic information, financial information, and EID status of listed companies. The green patent information involved in this article came from CIRD in the CNRDS database. The specific screening process of the sub-library was as follows. First, the CIRD sub-library was divided into eight groups A-H according to the International Patent Classification Table (IPC classification) to store the corresponding category of patent information separately. Hence, each group of patent information was divided separately, with each patent being extracted item by item; second, the Green List of International Patent Classification launched by the World Intellectual Property Organization (WIPO) provided the possibility to identify green patents. We refined the relevant green patent identification numbers to the finest IPC classification. Then, we used these classification numbers in the segmented and extracted CIRD font database to identify the value statistics. Third, the effective information about green patents was summarized. Finally, in accordance with previous relevant literature practices, samples with abnormal financial status or other abnormal conditions (ST, *ST, and S*ST companies) were deleted. Statistical or calculation biases were also eliminated. Only incorrect samples and companies with a duration of five years or more were retained. Finally, 883 listed companies in heavily polluting industries were obtained. The location distribution is shown in Figure 1. The data at the prefecture and city levels in China used in the robustness test in this article came from the 2008-2016 China City Statistical Yearbook. 


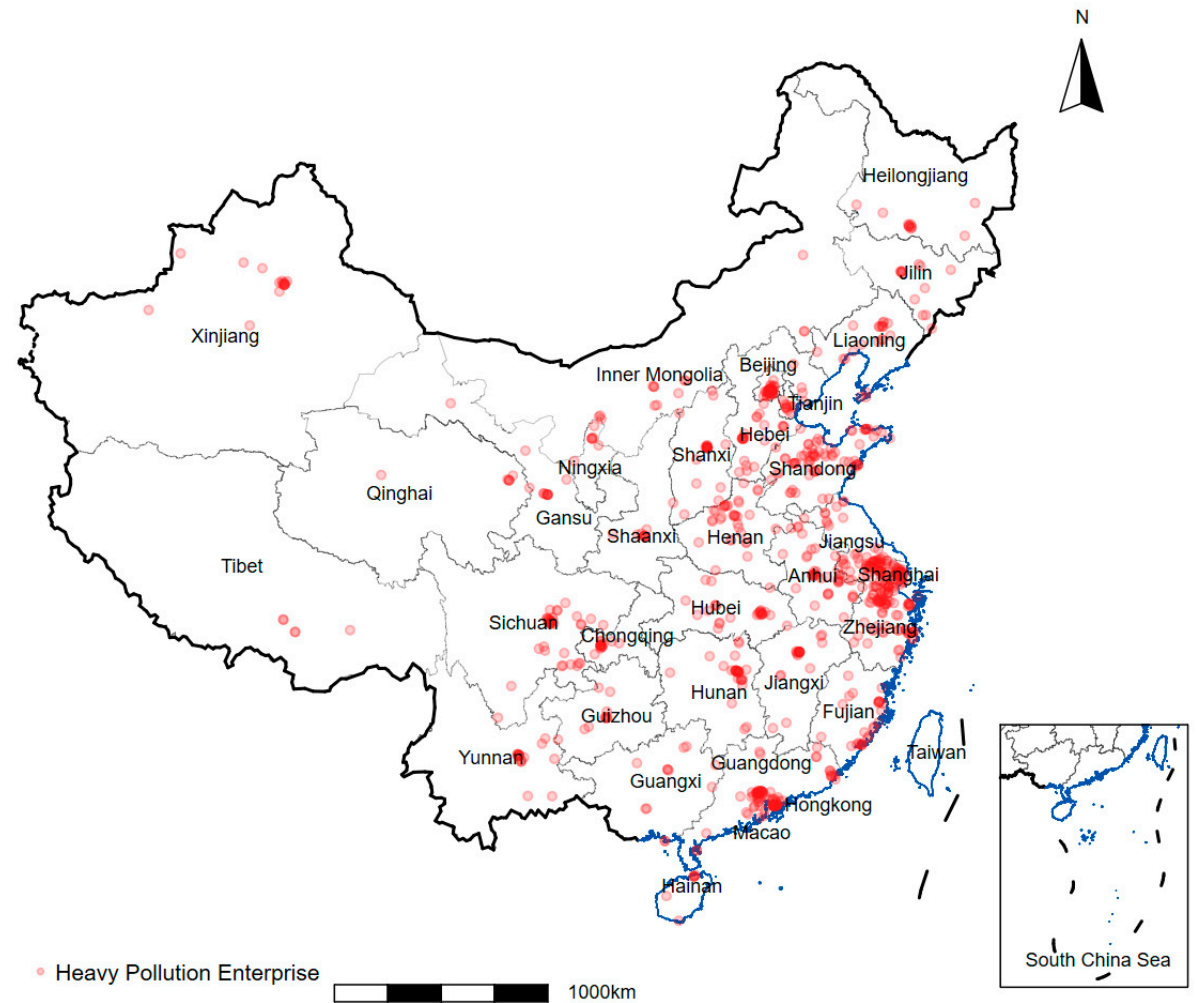

Figure 1. Location distribution map of listed heavily polluting companies in China.

\subsection{Variable Design}

In this study, GI is the explained variable. Innovation is a multi-stage process, which includes R\&D investment, invention, patents, and innovation activities (production or market launch). The advantage of patents as a measure of innovation is that patents are easy to obtain and can be subdivided into different technical fields. In addition, for several years, researchers have always believed that patents are one of the most important innovation indicators to measure the results of technological development [66]. One of the main outputs of the GI process is green patents. Therefore, this article selected two indicators: the amount of green patent applications or the absolute GI (AGI) from listed companies that year, and the proportion of green patent applications in all patent applications or relative GI (RGI) within the year to measure the company's GI level. The former represents the absolute level of corporate GI, and the latter indicates the relative level of GI. The green patent application was adopted instead of the green patent authorization because applying for a green patent is the most direct technical reflection of an enterprise after internal and external influences. Moreover, it is more stable, reliable, and timely than the authorized green patent [67]. In addition, compared with the number of pure green patents, the proportion of green patents reflects the relative importance of enterprises to green patents. At the same time, it effectively eliminates other unobservable factors that can have an impact on innovation $[68,69]$.

As an explanatory variable, the construction of EID indicators is the core of this article. This work followed the content analysis method [70,71] to evaluate the EID level of the research object quantitatively. On the basis of the environmental research data of relevant listed companies in the CSMAR database combined with the practice of China's environmental supervision in recent years, this study designed a set of EID indicators, including 5 first-level indicators and 26 second-level indicators, as shown in Table 1. For the secondary indicators, records that do not disclose corresponding environmental information were scored with 0 points, records disclosing corresponding environmental information qualitatively were scored with 1 point, and records disclosing corresponding 
environmental information with quantitative description (monetary/numerical description) were scored with 2 points. The values were summed up to obtain the total score for EID. Judging from the EID indicator trend in Figure 2, for both the total annual EID score and the average score the quality of the EID of listed companies in China's heavily polluting industry increased yearly. Moreover, the growth rate has been evident since 2015, which was also confirmed from the side. Thus, the new Environmental Protection Law officially implemented in 2015 in China has had a significant policy effect on corporate EID.

Table 1. An evaluation system for EID developed for listed companies.

\begin{tabular}{|c|c|}
\hline Primary Indicators & Secondary Indicators \\
\hline \multirow{3}{*}{ Disclosure vehicle } & Annual report \\
\hline & Social responsibility report \\
\hline & Environmental report \\
\hline \multirow{7}{*}{ Environmental management } & Environmental protection concept, environmental policy and environmental goals, etc. \\
\hline & Environmental protection management system \\
\hline & Environmental Education and Training \\
\hline & Environmental protection special action \\
\hline & Environmental incident emergency mechanism \\
\hline & Environmental honor or award \\
\hline & "Three Simultaneity" System \\
\hline \multirow{6}{*}{ Environmental liabilities } & Wastewater discharge \\
\hline & $\mathrm{SO}_{2}$ emissions \\
\hline & $\mathrm{CO}_{2}$ emissions \\
\hline & COD emissions \\
\hline & Smoke and dust emissions \\
\hline & Industrial solid waste generation \\
\hline \multirow{4}{*}{$\begin{array}{l}\text { Environmental supervision and agency } \\
\text { certification }\end{array}$} & Key pollution monitoring unit \\
\hline & Pollutant discharge standards \\
\hline & Sudden environmental accidents, illegal incidents, petition cases, etc. \\
\hline & ISO14001 certification \\
\hline \multirow{6}{*}{$\begin{array}{l}\text { Environmental performance } \\
\text { and governance }\end{array}$} & Waste gas emission reduction treatment \\
\hline & Wastewater emission reduction treatment \\
\hline & Smoke and dust control \\
\hline & Solid waste utilization and disposal \\
\hline & Control of noise, light pollution, radiation, etc. \\
\hline & Implementation of cleaner production \\
\hline
\end{tabular}

The control variables included enterprise scale (Scale), age (Age), financial leverage (Leverage), capital intensity (Capital), competitiveness (Competition), and Tobin's $Q$ value (Tobin's $Q$ ). The larger the enterprise, the more it may lead to economies of a large scale; this outcome is more conducive to controlling resources and to cultivating better employees [72], which is positively correlated with innovation performance. In terms of the age of an enterprise, one view is that the innovation consciousness of an enterprise is positively related to the time it was established [73]. However, another view is based on the theory of organizational inertia, which posits that the age of an enterprise is an important obstacle to innovation [74]. Moreover, companies with more fixed assets are more active in seeking innovation and environmental protection than companies with fewer fixed assets because 
the former has a greater risk of failure [75]. At the same time, Tobin's $Q$ value is an important and widely accepted corporate performance measurement standard [76] and represents the relationship between the market value of a company and the replacement value of assets [77]. The definition and descriptive statistics of specific related variables are shown in Table 2.

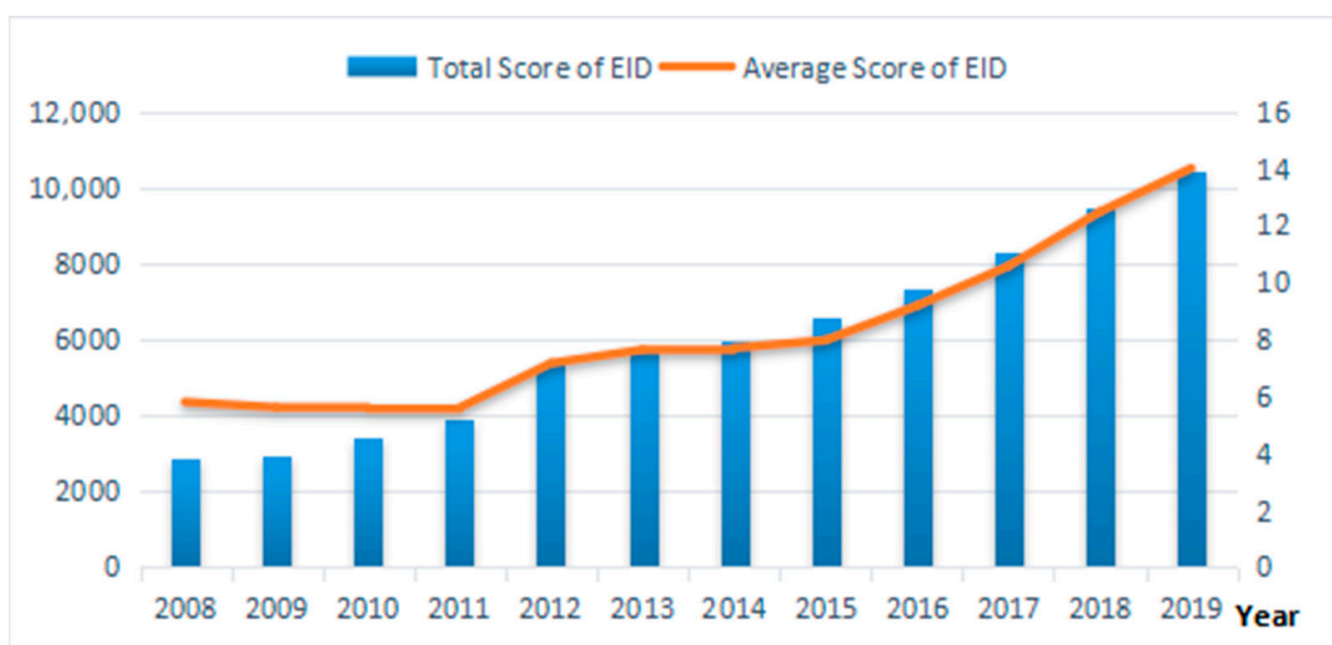

Figure 2. Trend of environmental information disclosure.

Table 2. Summary statistics.

\begin{tabular}{|c|c|c|c|c|c|c|}
\hline Variables & Variable Definition & Obs & Mean & SD & Min & Max \\
\hline AGI & Number of green patents & 8533 & 0.65 & 2.43 & 0.00 & 18.00 \\
\hline RGI & Percentage of green patents & 8533 & 0.04 & 0.13 & 0.00 & 0.83 \\
\hline EID & Total score of environmental information disclosure & 8533 & 8.41 & 7.24 & 1.00 & 35.00 \\
\hline Subsidy & $\begin{array}{c}\text { Logarithm of government's subsidies for innovation and } \\
\text { energy saving }\end{array}$ & 5727 & 12.77 & 4.06 & 0.00 & 21.42 \\
\hline Attention & $\begin{array}{l}\text { Logarithm of the number of news of the company that } \\
\text { appeared in newspapers and online media }\end{array}$ & 8533 & 5.25 & 1.04 & 0.00 & 10.17 \\
\hline Cost & $\begin{array}{l}\text { Multiply the ratio of interest expense to total average } \\
\qquad \text { debt by } 100\end{array}$ & 7699 & 2.70 & 1.65 & 0.15 & 8.03 \\
\hline Scale & Logarithm of employees & 8533 & 7.80 & 1.22 & 2.71 & 13.22 \\
\hline Age & The number of years the company has been listed & 8533 & 10.55 & 6.55 & 0.00 & 27.00 \\
\hline Leverage & The ratio of total liabilities to total assets & 8533 & 0.44 & 0.22 & 0.05 & 1.05 \\
\hline Capital & Logarithm of fixed capital per capita & 8529 & 12.96 & 1.00 & 10.64 & 15.92 \\
\hline Competition & The ratio of operating profit to main business income & 8531 & 0.07 & 0.18 & -0.84 & 0.57 \\
\hline Tobin's Q & Tobin's Q & 8533 & 2.13 & 1.68 & 0.21 & 9.63 \\
\hline FA & The ratio of local budget expenditure to budget revenue & 4798 & 1.53 & 0.89 & 0.82 & 10.09 \\
\hline $\mathrm{HC}$ & $\begin{array}{c}\text { The ratio of the number of students in local colleges and } \\
\text { universities to the total population }\end{array}$ & 5719 & 0.04 & 0.03 & 0.00 & 0.12 \\
\hline FDI & $\begin{array}{l}\text { The ratio of industrial output of foreign-invested } \\
\text { enterprises to total industrial output }\end{array}$ & 5688 & 0.15 & 0.14 & 0.00 & 0.46 \\
\hline ER & Local $\mathrm{SO}_{2}$ removal rate & 5410 & 0.56 & 0.28 & 0.00 & 0.97 \\
\hline
\end{tabular}

In addition, to verify Hypotheses $2-4$, this study introduces three intermediary variables, namely, the government-level innovation energy-saving subsidy variable (Subsidy), the social-level media attention variable (Attention), and the enterprise-level debt financing 
cost variable (Cost). The government's innovative energy-saving subsidy variables used the details of project names and amounts of government subsidies in the notes to the financial statements of the CSMAR database to filter out keywords including "innovation," "R\&D," "new products," "energy saving," "environmental protection," and "reduction." Government energy-saving innovation subsidy projects with keywords such as "exhaustion" and "low-carbon" were used to sum up the amount. Finally, the logarithm was taken. The social media attention variables were based on financial news-related data in the CNRDS database, including news reports from 8 major financial newspapers and 20 mainstream online financial media organizations. The amount of company news appearing in news reports was aggregated. Then, the logarithm was taken. The variable of the debt financing cost of a company was obtained by using the company's interest expense/average total debt, multiplied by 100 [78,79].

\subsection{Model Setting}

This study has two dependent variables, namely, the AGI and the RGI of each company. The AGI can only be a non-negative integer. Hence, Poisson regression is more suitable than the general least squares method. To adjust the overdispersion problem, this study uses the negative binomial model, which is a generalization of the Poisson model [80]. Therefore, two benchmark models are used:

$$
\begin{aligned}
& \mathrm{E}\left(\mathrm{AGI}_{\mathrm{it}} \mid \mathrm{X}\right)=\exp \left(\beta_{0}+\beta_{1} \mathrm{EID}_{\mathrm{it}}+\beta_{\mathrm{j}} \text { Controls }_{i t}+\text { Year FE }+ \text { City FE }+\varepsilon_{i t}\right) \\
& \mathrm{RGI}_{\mathrm{it}}=\beta_{0}+\beta_{1} \mathrm{EID}_{\mathrm{it}}+\beta_{\mathrm{j}} \text { Controls }_{\mathrm{it}}+\text { Year FE }+ \text { City FE }+\varepsilon_{\mathrm{it}}
\end{aligned}
$$

Equations (1) and (2) are the negative binomial model and the least squares model with the dependent variables AGI and RGI, respectively. Among them, the subscript i represents the company, and $t$ represents the time. EID represents the level of corporate environmental information disclosure, and Controls represents a series of control variables, including corporate scale (Scale), age (Age), financial leverage (Leverage), capital intensity (Capital), competitiveness (Competition), and Tobin's Q value (Tobin's Q). Year FE represents the time fixed effect, City FE represents the regional fixed effect, and $\varepsilon_{i t}$ represents the residual term.

\section{Empirical Results}

\subsection{Preliminary Regression Results}

To verify Hypothesis 1, this study adopts the Hausmann test and selects the negative binomial regression and least square regression models with random effects. The regression results are shown in Table 3. Models 1-2 are negative binomial regressions used when the dependent variable is the enterprise AGI. Models 3-4 are panel regressions used when the dependent variable is the enterprise RGI. Models 2 and 4 control the time fixed effects and the regional fixed effects on the basis of Model 1 and Model 3. In Model 1 and Model 2, the regression coefficients of EID were both positively significant $(\beta=0.033, p<1 \% ; \beta=0.026$, $p<1 \%$;), which shows that as the quality of EID improved, the AGI of Chinese companies also improves significantly. In Model 3 and Model 4, the regression coefficients of EID were also positively significant $(\beta=0.001, p<1 \%$; $\beta=0.001, p<1 \%$; ), which also indicates that the level of corporate EID has further improved and promoted RGI ability. Therefore, Hypothesis 1 is supported. As far as the regression results of the control variables are concerned, the scale of the enterprise and the capital intensity have played a positive role in the GI of the enterprise to a certain extent, which is consistent with the analysis when the control variables were selected in this article. The age of a company generally has a negative effect on GI, possibly because the longer the company goes public, the more solidified its industrial structure and management mechanism system will be, and the less enthusiasm for GI it will have. Corporate financial leverage also has a negative impact on corporate GI to a certain extent, thus indicating that the corporate debt burden affects its investment in GI-related fields that may have long return periods. However, the corporate competitiveness and the value of Tobin's $Q$ do not have a significant impact on GI. 
Table 3. The impact of EID on GI.

\begin{tabular}{|c|c|c|c|c|}
\hline & (1) & (2) & (3) & (4) \\
\hline & \multicolumn{2}{|c|}{ AGI } & \multicolumn{2}{|c|}{ RGI } \\
\hline EID & $\begin{array}{c}0.033 * * * \\
(0.005)\end{array}$ & $\begin{array}{c}0.026^{* * *} \\
(0.005)\end{array}$ & $\begin{array}{c}0.001 * * * \\
(0.000)\end{array}$ & $\begin{array}{c}0.001^{* * *} \\
(0.000)\end{array}$ \\
\hline Scale & $\begin{array}{c}0.449 \text { *** } \\
(0.046)\end{array}$ & $\begin{array}{c}0.502 * * * \\
(0.050)\end{array}$ & $\begin{array}{l}0.004^{*} \\
(0.002)\end{array}$ & $\begin{array}{c}0.003 \\
(0.002)\end{array}$ \\
\hline Age & $\begin{array}{l}-0.012 \\
(0.007)\end{array}$ & $\begin{array}{c}-0.054^{* * *} \\
(0.010)\end{array}$ & $\begin{array}{c}-0.001 \text { * } \\
(0.000)\end{array}$ & $\begin{array}{c}-0.002 \text { *** } \\
(0.000)\end{array}$ \\
\hline Leverage & $\begin{array}{c}-0.808^{* * *} \\
(0.241)\end{array}$ & $\begin{array}{c}-0.598^{* *} \\
(0.247)\end{array}$ & $\begin{array}{l}-0.000 \\
(0.010)\end{array}$ & $\begin{array}{c}0.006 \\
(0.010)\end{array}$ \\
\hline Capital & $\begin{array}{c}0.264^{* * *} \\
(0.051)\end{array}$ & $\begin{array}{c}0.224^{* * *} \\
(0.055)\end{array}$ & $\begin{array}{l}0.004^{* *} \\
(0.002)\end{array}$ & $\begin{array}{c}0.003 \\
(0.002)\end{array}$ \\
\hline Competition & $\begin{array}{l}-0.142 \\
(0.262)\end{array}$ & $\begin{array}{l}-0.048 \\
(0.276)\end{array}$ & $\begin{array}{c}0.007 \\
(0.009)\end{array}$ & $\begin{array}{c}0.009 \\
(0.009)\end{array}$ \\
\hline Tobin's Q & $\begin{array}{c}0.021 \\
(0.031)\end{array}$ & $\begin{array}{c}0.016 \\
(0.032)\end{array}$ & $\begin{array}{c}0.000 \\
(0.001)\end{array}$ & $\begin{array}{c}-0.000 \\
(0.001)\end{array}$ \\
\hline Constant & $\begin{array}{c}-7.568^{* * *} \\
(0.803)\end{array}$ & $\begin{array}{c}-9.001^{* * *} \\
(1.014)\end{array}$ & $\begin{array}{l}-0.051 \\
(0.035)\end{array}$ & $\begin{array}{l}-0.030 \\
(0.044)\end{array}$ \\
\hline Year FE & $\mathrm{NO}$ & YES & $\mathrm{NO}$ & YES \\
\hline City FE & $\mathrm{NO}$ & YES & $\mathrm{NO}$ & YES \\
\hline $\mathrm{N}$ & 8527 & 8527 & 8527 & 8527 \\
\hline Log likelihood & -5449.037 & -5318.838 & & \\
\hline Wald Chi Square & 289.384 & 563.614 & 42.176 & 109.960 \\
\hline Prob > chi2 & 0.000 & 0.000 & 0.000 & 0.000 \\
\hline $\mathrm{R}^{2}$ & & & 0.020 & 0.037 \\
\hline
\end{tabular}

Note: figures in () are standard error; ${ }^{* * *},{ }^{* *}$, and ${ }^{*}$ indicate significance at the $1 \%, 5 \%$, and $10 \%$ levels, respectively.

\subsection{Mechanism Analysis}

According to the above empirical analysis results, the improvement of EID quality can promote the GI of enterprises. This section empirically explores the internal mechanism of this impact on the basis of the theoretical analysis in the previous section. Government-level innovation energy-saving subsidies, media attention and corporate-level debt financing costs were used to verify Hypotheses $2-4$.

On the basis of the latest test methods and interpretations of the intermediary effect $[81,82]$, this study conducts an intermediary test and analysis on the three variables innovative energy-saving subsidies, media attention, and debt financing costs. The significance and size of the regression coefficients between different models were compared. When AGI is the dependent variable, it does not match the panel random effects model used in the intermediary test. Thus, this article only uses the relative value of GI as the dependent variable test mechanism. Table 4 lists the results of the mechanism test. Model 1 and Model 2 test the possible intermediate variable innovation energy-saving subsidies. Model 1 is the regression of EID to the intermediate variable innovation energy-saving subsidies. The coefficient of EID was positive and significant. Similar to the previous theoretical analysis, the improvement of the quality of corporate EID serves as a signaling mechanism to induce the government to increase subsidies for corporate innovation and energy conservation. The coefficients of EID and subsidies in Model 2 were also positively significant, which shows that government subsidies have indeed improved the level of GI of enterprises. Taken together, the government's innovation and energy-saving subsidies are an intermediary variable for EID to affect RGI. Thus, Hypothesis 2 is established. 
Model 3 and Model 4 are tests of the possible mediating variables of media attention. The coefficient of EID in Model 3 was positive and significant, thus reflecting that the media attention of enterprises increased with the improvement of the quality of EID. However, in Model 4, the coefficient of attention was positive but not significant. Thus, a bootstrap test was required. According to the $95 \%$ bootstrap confidence interval [0.000, 0.000], the media attention effect was also a mediating effect. Hence, Hypothesis 3 is established. Model 5 and Model 6 test the mediation effect of corporate debt financing costs. The coefficient of EID in Model 5 was significantly negative, which indicates that improvement in the quality of corporate EID has indeed reduced debt financing costs. Meanwhile, the cost coefficient in Model 6 was negative but not significant. In the bootstrap test, the $95 \%$ bootstrap confidence interval was [-0.000,0.000]: the mediating effect of debt financing costs failed the test. Thus, Hypothesis 4 does not hold. One possible explanation is the environmental information that the company releases: a higher quality of disclosure entails that the signal transmission function enables banks and other credit institutions to simplify the process and to reduce cumbersome costs in their capital transactions with the company. However, its role may not be enough to affect the GI R\&D activities that require long-term and large-scale financial support.

Table 4. Impact mechanism of EID on GI.

\begin{tabular}{|c|c|c|c|c|c|c|}
\hline & (1) & (2) & (3) & (4) & (5) & (6) \\
\hline & Subsidy & RGI & Attention & RGI & Cost & RGI \\
\hline EID & $\begin{array}{c}0.055^{* * *} \\
(0.010)\end{array}$ & $\begin{array}{c}0.001^{* * *} \\
(0.000)\end{array}$ & $\begin{array}{c}0.007^{* * *} \\
(0.001)\end{array}$ & $\begin{array}{c}0.001^{* * *} \\
(0.000)\end{array}$ & $\begin{array}{c}-0.007^{* *} \\
(0.003)\end{array}$ & $\begin{array}{c}0.001 \text { *** } \\
(0.000)\end{array}$ \\
\hline Subsidy & & $\begin{array}{l}0.001 * * \\
(0.000)\end{array}$ & & & & \\
\hline Attention & & & & $\begin{array}{c}0.001 \\
(0.002)\end{array}$ & & \\
\hline Cost & & & & & & $\begin{array}{l}-0.000 \\
(0.001)\end{array}$ \\
\hline Scale & $\begin{array}{c}0.837^{* * * *} \\
(0.079)\end{array}$ & $\begin{array}{c}0.004 \\
(0.003)\end{array}$ & $\begin{array}{c}0.256^{* * *} \\
(0.012)\end{array}$ & $\begin{array}{c}0.002 \\
(0.002)\end{array}$ & $\begin{array}{c}-0.065^{* * *} \\
(0.025)\end{array}$ & $\begin{array}{c}0.002 \\
(0.002)\end{array}$ \\
\hline Age & $\begin{array}{c}-0.035^{* * *} \\
(0.013)\end{array}$ & $\begin{array}{c}-0.001 \text { ** } \\
(0.001)\end{array}$ & $\begin{array}{c}0.014^{* * *} \\
(0.003)\end{array}$ & $\begin{array}{c}-0.002^{* * *} \\
(0.000)\end{array}$ & $\begin{array}{c}0.005 \\
(0.005)\end{array}$ & $\begin{array}{c}-0.002 \text { *** } \\
(0.000)\end{array}$ \\
\hline Leverage & $\begin{array}{l}-0.043 \\
(0.400)\end{array}$ & $\begin{array}{c}0.002 \\
(0.014)\end{array}$ & $\begin{array}{c}0.143^{* * *} \\
(0.055)\end{array}$ & $\begin{array}{c}0.006 \\
(0.010)\end{array}$ & $\begin{array}{c}1.032 * * * \\
(0.119)\end{array}$ & $\begin{array}{c}0.008 \\
(0.011)\end{array}$ \\
\hline Capital & $\begin{array}{c}0.293^{* * *} \\
(0.082)\end{array}$ & $\begin{array}{l}0.005 * \\
(0.003)\end{array}$ & $\begin{array}{c}0.147^{* * *} \\
(0.012)\end{array}$ & $\begin{array}{c}0.002 \\
(0.002)\end{array}$ & $\begin{array}{c}0.250 * * * \\
(0.026)\end{array}$ & $\begin{array}{c}0.003 \\
(0.002)\end{array}$ \\
\hline Competition & $\begin{array}{c}-0.044 \\
(0.398)\end{array}$ & $\begin{array}{c}0.007 \\
(0.013)\end{array}$ & $\begin{array}{l}0.113^{* *} \\
(0.047)\end{array}$ & $\begin{array}{c}0.008 \\
(0.009)\end{array}$ & $\begin{array}{c}-1.077^{* * *} \\
(0.106)\end{array}$ & $\begin{array}{c}0.009 \\
(0.010)\end{array}$ \\
\hline Tobin's Q & $\begin{array}{c}0.023 \\
(0.047)\end{array}$ & $\begin{array}{c}0.000 \\
(0.002)\end{array}$ & $\begin{array}{c}0.145^{* * *} \\
(0.006)\end{array}$ & $\begin{array}{l}-0.001 \\
(0.001)\end{array}$ & $\begin{array}{c}-0.119^{* * *} \\
(0.014)\end{array}$ & $\begin{array}{l}-0.001 \\
(0.001)\end{array}$ \\
\hline Constant & $\begin{array}{c}2.232 \\
(1.500)\end{array}$ & $\begin{array}{l}-0.086 \\
(0.053)\end{array}$ & $\begin{array}{c}0.199 \\
(0.265)\end{array}$ & $\begin{array}{l}-0.029 \\
(0.045)\end{array}$ & $\begin{array}{c}-0.989^{*} \\
(0.506)\end{array}$ & $\begin{array}{l}-0.043 \\
(0.047)\end{array}$ \\
\hline Year FE & YES & YES & YES & YES & YES & YES \\
\hline City FE & YES & YES & YES & YES & YES & YES \\
\hline Boot 95\% CI & & & \multicolumn{2}{|c|}{$[0.000,0.000]$} & \multicolumn{2}{|c|}{$[-0.000,0.000]$} \\
\hline $\mathrm{N}$ & 5726 & 5726 & 8527 & 8527 & 7696 & 7696 \\
\hline $\mathrm{R}^{2}$ & 0.092 & 0.035 & 0.414 & 0.037 & 0.245 & 0.038 \\
\hline
\end{tabular}




\subsection{Robustness Tests}

To improve the reliability of the findings, this study adopts three robustness tests for the main results. First, the dependent and independent variables are replaced. In this study's benchmark regression, the dependent variable uses indicators related to green patent applications. However, under the Chinese scenario, patent application activities may be flooded with false and substandard patents, thus forming an innovation illusion [83]. Nevertheless, patent acquisition can reflect the innovation ability of an enterprise. Therefore, this study constructs two indicators of the number of green patents and the proportion of green patents that enterprises have obtained to re-evaluate the GI capabilities of enterprises. At the same time, to facilitate horizontal comparison, this study divides the actual score of the EID level by the highest possible score of all indicators, which is 38 points, and defines it as the EID index and a new independent variable. Table 5, Model 1, and Model 3 reflect the regression results after replacing the dependent and independent variables. The coefficients of EID were both positively significant, thus indicating that corporate EID promotes GI.

Table 5. Robustness tests for replacing variables and adding control variables.

\begin{tabular}{|c|c|c|c|c|}
\hline & \multicolumn{2}{|c|}{ AGI } & \multicolumn{2}{|c|}{ RGI } \\
\hline & (1) & (2) & (3) & (4) \\
\hline & $\begin{array}{l}\text { Replace Dependent and } \\
\text { Independent Variables }\end{array}$ & $\begin{array}{c}\text { Add City Level } \\
\text { Control Variables }\end{array}$ & $\begin{array}{l}\text { Replace Dependent and } \\
\text { Independent Variables }\end{array}$ & $\begin{array}{c}\text { Add City Level } \\
\text { Control Variables }\end{array}$ \\
\hline EID & $\begin{array}{l}0.816^{* * *} \\
(0.203)\end{array}$ & $\begin{array}{l}0.029^{* * * *} \\
(0.007)\end{array}$ & $\begin{array}{l}0.034^{* * *} \\
(0.010)\end{array}$ & $\begin{array}{l}0.001 * * * \\
(0.000)\end{array}$ \\
\hline Scale & $\begin{array}{c}0.459 * * * \\
(0.057)\end{array}$ & $\begin{array}{l}0.561 * * * \\
(0.070)\end{array}$ & $\begin{array}{c}0.002 \\
(0.002)\end{array}$ & $\begin{array}{c}0.002 \\
(0.003)\end{array}$ \\
\hline Age & $\begin{array}{l}-0.043^{* * *} \\
(0.012)\end{array}$ & $\begin{array}{l}-0.070^{* * *} \\
(0.014)\end{array}$ & $\begin{array}{l}-0.002 * * * \\
(0.000)\end{array}$ & $\begin{array}{l}-0.002 * * * \\
(0.001)\end{array}$ \\
\hline Leverage & $\begin{array}{l}-0.607 * * \\
(0.276)\end{array}$ & $\begin{array}{l}-0.915^{* *} \\
(0.362)\end{array}$ & $\begin{array}{c}0.016 \\
(0.010)\end{array}$ & $\begin{array}{c}0.011 \\
(0.015)\end{array}$ \\
\hline Capital & $\begin{array}{l}0.204 * * * \\
(0.062)\end{array}$ & $\begin{array}{l}0.330 * * * \\
(0.077)\end{array}$ & $\begin{array}{c}0.002 \\
(0.002)\end{array}$ & $\begin{array}{l}0.005^{*} \\
(0.003)\end{array}$ \\
\hline Competition & $\begin{array}{c}0.084 \\
(0.298)\end{array}$ & $\begin{array}{l}-1.052^{* * *} \\
(0.385)\end{array}$ & $\begin{array}{l}0.017^{*} \\
(0.009)\end{array}$ & $\begin{array}{l}-0.007 \\
(0.014)\end{array}$ \\
\hline Tobin's Q & $\begin{array}{l}-0.042 \\
(0.037)\end{array}$ & $\begin{array}{l}-0.029 \\
(0.046)\end{array}$ & $\begin{array}{l}-0.001 \\
(0.001)\end{array}$ & $\begin{array}{l}-0.002 \\
(0.002)\end{array}$ \\
\hline FA & & $\begin{array}{l}-0.146 \\
(0.104)\end{array}$ & & $\begin{array}{l}-0.003 \\
(0.004)\end{array}$ \\
\hline $\mathrm{HC}$ & & $\begin{array}{l}-7.792^{* * *} \\
(2.574)\end{array}$ & & $\begin{array}{l}-0.333^{* * *} \\
(0.119)\end{array}$ \\
\hline FDI & & $\begin{array}{l}-0.815 \\
(0.899)\end{array}$ & & $\begin{array}{l}-0.009 \\
(0.041)\end{array}$ \\
\hline ER & & $\begin{array}{c}0.316 \\
(0.272)\end{array}$ & & $\begin{array}{l}-0.011 \\
(0.014)\end{array}$ \\
\hline Constant & $\begin{array}{c}-7.653^{* * *} \\
(1.185) \\
\end{array}$ & $\begin{array}{l}-9.216^{* * *} \\
(1.441) \\
\end{array}$ & $\begin{array}{l}-0.017 \\
(0.043)\end{array}$ & $\begin{array}{l}-0.025 \\
(0.059) \\
\end{array}$ \\
\hline Year FE & YES & YES & YES & YES \\
\hline City FE & YES & YES & YES & YES \\
\hline $\mathrm{N}$ & 8527 & 4444 & 8527 & 4444 \\
\hline Log likelihood & -4275.912 & -2865.900 & & \\
\hline Wald Chi Square & 429.105 & 309.318 & 104.612 & 94.632 \\
\hline Prob > chi2 & 0.000 & 0.000 & 0.000 & 0.000 \\
\hline$R^{2}$ & & & 0.032 & 0.050 \\
\hline
\end{tabular}

Note: figures in () are standard error; ${ }^{* * *}, * *$ and ${ }^{*}$ indicate significance at the $1 \%, 5 \%$, and $10 \%$ levels, respectively. 
Second, at the city level, given that the local fiscal level, foreign investment level, human capital level, and environmental regulation intensity may affect corporate EID and GI at the same time, this study adds the city-level fiscal autonomy (FA), human capital (HC), foreign investment (FDI), and environmental regulations (ER) to control for possible endogenous problems. Given the limitation of some indicators, the sample years are 2008-2016. The regression results are shown in Model 2 and Model 4 in Table 5. The coefficients of EID were positively significant, thus indicating that the benchmark results of this study are still established.

Third, from the statistical analysis of Figure 2 above, 2015-2019 was the peak period for the increase in EID of listed companies. To examine whether differences exist in the impact of EID on corporate GI at different stages, this study divided the sample into two sub-samples from 2008 to 2014 and 2015 to 2019, and then re-examined them. Table 6 reports the empirical results. The results demonstrate that, in the years of rapid growth in EID (2015-2019) the promotion of EID on the company's GI was greater than that of the control years (2008-2014). EID will indeed have a positive impact on the company's GI, especially during the rapid growth stage of EID. In general, the main conclusions of this article will not change substantially.

Table 6. Robustness test of annual regression.

\begin{tabular}{|c|c|c|c|c|}
\hline & \multicolumn{2}{|c|}{ AGI } & \multicolumn{2}{|c|}{ RGI } \\
\hline & (1) & (2) & (3) & (4) \\
\hline & Before 2015 & After 2015 Inclusive & Before 2015 & After 2015 Inclusive \\
\hline EID & $\begin{array}{l}0.020 * * \\
(0.008)\end{array}$ & $\begin{array}{c}0.031^{* * *} \\
(0.007)\end{array}$ & $\begin{array}{l}0.001 * * \\
(0.000)\end{array}$ & $\begin{array}{c}0.001^{* * * *} \\
(0.000)\end{array}$ \\
\hline Scale & $\begin{array}{c}0.621^{* * *} \\
(0.075)\end{array}$ & $\begin{array}{c}0.574^{* * *} \\
(0.071)\end{array}$ & $\begin{array}{c}0.001 \\
(0.003)\end{array}$ & $\begin{array}{c}0.005 \\
(0.003)\end{array}$ \\
\hline Age & $\begin{array}{c}-0.080 * * * \\
(0.015)\end{array}$ & $\begin{array}{c}-0.046^{* * *} \\
(0.012)\end{array}$ & $\begin{array}{c}-0.002 \text { *** } \\
(0.001)\end{array}$ & $\begin{array}{c}-0.001 \text { *** } \\
(0.001)\end{array}$ \\
\hline Leverage & $\begin{array}{c}-0.823^{* *} \\
(0.391)\end{array}$ & $\begin{array}{l}-0.379 \\
(0.363)\end{array}$ & $\begin{array}{c}0.022 \\
(0.015)\end{array}$ & $\begin{array}{c}0.001 \\
(0.017)\end{array}$ \\
\hline Capital & $\begin{array}{c}0.346^{* * *} \\
(0.082)\end{array}$ & $\begin{array}{c}0.246^{* * *} \\
(0.081)\end{array}$ & $\begin{array}{c}0.005 \\
(0.003) \\
\end{array}$ & $\begin{array}{c}0.003 \\
(0.003) \\
\end{array}$ \\
\hline Competition & $\begin{array}{l}-0.264 \\
(0.478)\end{array}$ & $\begin{array}{l}-0.113 \\
(0.349)\end{array}$ & $\begin{array}{c}0.007 \\
(0.013)\end{array}$ & $\begin{array}{c}0.002 \\
(0.014)\end{array}$ \\
\hline Tobin's Q & $\begin{array}{l}-0.053 \\
(0.059) \\
\end{array}$ & $\begin{array}{c}0.037 \\
(0.040) \\
\end{array}$ & $\begin{array}{l}-0.001 \\
(0.002) \\
\end{array}$ & $\begin{array}{l}-0.000 \\
(0.002)\end{array}$ \\
\hline Constant & $\begin{array}{c}-9.976^{* * *} \\
(1.526)\end{array}$ & $\begin{array}{c}-10.418^{* * * *} \\
(1.415)\end{array}$ & $\begin{array}{l}-0.029 \\
(0.057)\end{array}$ & $\begin{array}{l}-0.064 \\
(0.060)\end{array}$ \\
\hline Year FE & YES & YES & YES & YES \\
\hline City FE & YES & YES & YES & YES \\
\hline $\mathrm{N}$ & 4603 & 3924 & 4603 & 3924 \\
\hline Log likelihood & -2547.321 & -2887.713 & & \\
\hline Wald Chi Square & 287.229 & 300.606 & 79.194 & 75.744 \\
\hline Prob > chi2 & 0.000 & 0.000 & 0.001 & 0.001 \\
\hline $\mathrm{R}^{2}$ & & & 0.041 & 0.040 \\
\hline
\end{tabular}

Note: figures in () are standard error; ${ }^{* *}$ and ${ }^{*}$ indicate significance at the $1 \%$ and $5 \%$ levels, respectively. 


\section{Heterogeneity Analysis}

\subsection{Patent Category Heterogeneity}

This article mainly uses patents to measure the level of corporate GI. Moreover, EID may induce different types of green patent innovation activities. Therefore, in light of the actual situation, this section examines the heterogeneity of two types of patents.

The first type was based on the green list of international patent classifications provided by WIPO. The study divided green patents into seven categories, namely, alternative energy production, transportation, energy conservation, waste management, agriculture and forestry, management regulations and design, and nuclear power, to examine whether EID has a heterogeneous impact on GI in different technical fields. In specific practice, few effective observations have been made for transportation, agriculture and forestry, management regulations and design, and nuclear power patents. Thus, the effect or the final result was impossible to iterate. Therefore, this section only distinguishes alternative energy production. In addition, the category of energy conservation and waste management has three types of patents. However, given the limited space, this section only reports the regression results of corporate GI measured by the absolute value of green patents. Models 1-3 in Table 7 demonstrate that EID promotes enterprise GI activities in alternative energy production, energy conservation, and waste management. Moreover, it has the greatest effect on energy conservation innovation.

Table 7. Regression results of the heterogeneity of green patents.

\begin{tabular}{|c|c|c|c|c|c|}
\hline & (1) & (2) & (3) & (4) & (5) \\
\hline & $\begin{array}{l}\text { Alternative Energy } \\
\text { Production }\end{array}$ & Energy Conservation & Waste Management & Invention Patents & Utility Model Patents \\
\hline EID & $\begin{array}{l}0.019 * * \\
(0.008)\end{array}$ & $\begin{array}{l}0.039 * * * \\
(0.010)\end{array}$ & $\begin{array}{l}0.024^{* * *} \\
(0.006)\end{array}$ & $\begin{array}{l}0.022 * * * \\
(0.006)\end{array}$ & $\begin{array}{l}0.020 * * * \\
(0.006)\end{array}$ \\
\hline Scale & $\begin{array}{l}0.506 * * * \\
(0.066)\end{array}$ & $\begin{array}{l}0.667 * * * \\
(0.100)\end{array}$ & $\begin{array}{l}0.427^{* * * *} \\
(0.055)\end{array}$ & $\begin{array}{l}0.468^{* * * *} \\
(0.052)\end{array}$ & $\begin{array}{l}0.440^{* * * *} \\
(0.060)\end{array}$ \\
\hline Age & $\begin{array}{l}-0.036^{* *} \\
(0.016)\end{array}$ & $\begin{array}{l}-0.051^{* * *} \\
(0.019)\end{array}$ & $\begin{array}{c}-0.046^{* * *} \\
(0.012)\end{array}$ & $\begin{array}{l}-0.039^{* * *} \\
(0.012)\end{array}$ & $\begin{array}{l}-0.050^{* * *} \\
(0.013)\end{array}$ \\
\hline Leverage & $\begin{array}{l}-0.475 \\
(0.412)\end{array}$ & $\begin{array}{l}-1.707^{* * *} \\
(0.562)\end{array}$ & $\begin{array}{l}-0.665^{* *} \\
(0.302)\end{array}$ & $\begin{array}{l}-0.514^{*} \\
(0.289)\end{array}$ & $\begin{array}{l}-1.085^{* * *} \\
(0.344)\end{array}$ \\
\hline Capital & $\begin{array}{l}0.202 * * \\
(0.085)\end{array}$ & $\begin{array}{l}0.342^{* * * *} \\
(0.112)\end{array}$ & $\begin{array}{l}0.359^{* * * *} \\
(0.069)\end{array}$ & $\begin{array}{l}0.224^{* * * *} \\
(0.063)\end{array}$ & $\begin{array}{l}0.170 * * \\
(0.073)\end{array}$ \\
\hline Competition & $\begin{array}{c}0.751 \\
(0.500)\end{array}$ & $\begin{array}{l}-1.297 * * \\
(0.610)\end{array}$ & $\begin{array}{l}-0.174 \\
(0.334)\end{array}$ & $\begin{array}{c}0.126 \\
(0.318)\end{array}$ & $\begin{array}{l}-0.487 \\
(0.401)\end{array}$ \\
\hline Tobin's Q & $\begin{array}{c}0.054 \\
(0.052)\end{array}$ & $\begin{array}{l}-0.068 \\
(0.085)\end{array}$ & $\begin{array}{l}-0.032 \\
(0.043)\end{array}$ & $\begin{array}{c}0.012 \\
(0.037)\end{array}$ & $\begin{array}{l}-0.052 \\
(0.050)\end{array}$ \\
\hline Constant & $\begin{array}{l}-9.677^{* * *} \\
(1.458)\end{array}$ & $\begin{array}{l}-12.851^{* * *} \\
(2.159)\end{array}$ & $\begin{array}{l}-10.002 * * * \\
(1.226)\end{array}$ & $\begin{array}{l}-8.823^{* * *} \\
(1.113)\end{array}$ & $\begin{array}{l}-8.679 * * * \\
(1.383)\end{array}$ \\
\hline Year FE & YES & YES & YES & YES & YES \\
\hline City FE & YES & YES & YES & YES & YES \\
\hline $\mathrm{N}$ & 8527 & 8527 & 8527 & 8527 & 8527 \\
\hline Log likelihood & -2339.473 & -1365.575 & -3713.382 & -4126.047 & -3117.055 \\
\hline Wald Chi Square & 254.425 & 244.203 & 457.890 & 409.291 & 375.764 \\
\hline Prob > chi2 & 0.000 & 0.000 & 0.000 & 0.000 & 0.000 \\
\hline
\end{tabular}

Note: figures in () are standard error; ${ }^{* * *}, * *$, and ${ }^{*}$ indicate significance at the $1 \%, 5 \%$, and $10 \%$ levels, respectively.

In the second category, green patents were divided into invention patents and utility model patents. Table 7, Model 4, and Model 5 demonstrate that EID also promotes the level of GI corresponding to enterprise invention patents and utility model patents. In comparison, it has a greater role in promoting the GI activities of invention patents. 


\subsection{Enterprise Heterogeneity}

In emerging economies such as China, corporate ownership is considered an important institutional factor. The cognitive logic, institutional logic, and resource endowments of enterprises with different ownership structures are quite different, which may lead to EID and GI. Table 8, Model 1, and Model 2 report the regression results of distinguishing between state-owned enterprises and private enterprises. The EID of state-owned enterprises was more conducive to GI activities than private enterprises. This observation reflects the efficiency of state-owned enterprises compared with private enterprises. With lower market vitality, state-owned enterprises respond more actively to government policies to obtain support from more national resources. Moreover, they tend to disclose more environmental information, thereby promoting GI to a greater extent.

Table 8. Regression results of the heterogeneity of enterprise ownership and city levels.

\begin{tabular}{|c|c|c|c|c|}
\hline & (1) & (2) & (3) & (4) \\
\hline & State-Owned Enterprises & Private Enterprises & $\begin{array}{c}\text { High-Level } \\
\text { Administrative Cities }\end{array}$ & $\begin{array}{c}\text { Low-Level } \\
\text { Administrative Cities }\end{array}$ \\
\hline EID & $\begin{array}{l}0.023 * * * \\
(0.006)\end{array}$ & $\begin{array}{l}0.019 * * \\
(0.008)\end{array}$ & $\begin{array}{c}0.011 \\
(0.008)\end{array}$ & $\begin{array}{l}0.028 * * * \\
(0.006)\end{array}$ \\
\hline Scale & $\begin{array}{l}0.515^{* * *} \\
(0.073)\end{array}$ & $\begin{array}{l}0.471^{* * *} \\
(0.086)\end{array}$ & $\begin{array}{l}0.687^{* * *} \\
(0.085)\end{array}$ & $\begin{array}{l}0.510 * * * \\
(0.063)\end{array}$ \\
\hline Age & $\begin{array}{c}-0.075^{* * *} \\
(0.019)\end{array}$ & $\begin{array}{c}-0.084^{* * *} \\
(0.016)\end{array}$ & $\begin{array}{l}-0.014 \\
(0.021)\end{array}$ & $\begin{array}{c}-0.065^{* * *} \\
(0.012)\end{array}$ \\
\hline Leverage & $\begin{array}{c}-1.148^{* * *} \\
(0.357)\end{array}$ & $\begin{array}{l}-0.357 \\
(0.386)\end{array}$ & $\begin{array}{l}-0.765 \\
(0.487)\end{array}$ & $\begin{array}{l}-0.428 \\
(0.292)\end{array}$ \\
\hline Capital & $\begin{array}{l}0.249 * * * \\
(0.077)\end{array}$ & $\begin{array}{l}0.205^{* *} \\
(0.093)\end{array}$ & $\begin{array}{l}0.236 * * \\
(0.097)\end{array}$ & $\begin{array}{c}0.246 * * * \\
(0.069)\end{array}$ \\
\hline Competition & $\begin{array}{l}-0.517 \\
(0.382)\end{array}$ & $\begin{array}{c}0.582 \\
(0.445)\end{array}$ & $\begin{array}{l}-0.713 \\
(0.545)\end{array}$ & $\begin{array}{c}0.124 \\
(0.319)\end{array}$ \\
\hline Tobin's Q & $\begin{array}{l}-0.019 \\
(0.061)\end{array}$ & $\begin{array}{c}0.024 \\
(0.043)\end{array}$ & $\begin{array}{l}0.144^{* *} \\
(0.067)\end{array}$ & $\begin{array}{l}-0.017 \\
(0.038)\end{array}$ \\
\hline Constant & $\begin{array}{l}-8.278^{* * *} \\
(1.643)\end{array}$ & $\begin{array}{l}-8.500 * * * \\
(1.720)\end{array}$ & $\begin{array}{l}-10.843^{* * *} \\
(1.694)\end{array}$ & $\begin{array}{l}-9.010 * * * \\
(1.239)\end{array}$ \\
\hline Year FE & YES & YES & YES & YES \\
\hline City FE & YES & YES & YES & YES \\
\hline $\mathrm{N}$ & 3901 & 4173 & 3040 & 5487 \\
\hline Log likelihood & $-2.8 \times 10^{3}$ & $-2.3 \times 10^{3}$ & $-1.5 \times 10^{3}$ & $-3.7 \times 10^{3}$ \\
\hline Wald Chi Square & 407.859 & 212.002 & 210.486 & 390.759 \\
\hline Prob > chi2 & 0.000 & 0.000 & 0.000 & 0.000 \\
\hline
\end{tabular}

Note: figures in () are standard error; ${ }^{* *}$ and * indicate significance at the $1 \%$ and $5 \%$ levels, respectively.

\subsection{City Heterogeneity}

In China, there are huge differences among cities. Cities with high administrative levels can obtain more resource allocation from the central government, which is reflected in preferential policies, financial appropriations, and preferential use of foreign direct investment. Compared with enterprises in cities with lower administrative levels, they are different in environmental awareness and $R \& D$ investment. This section defines provincial-level cities, sub-provincial-level cities, and provincial capital cities as high-level administrative cities. In addition, prefecture-level cities are called low-administrative cities, which were divided into two categories. Table 8, Model 3, and Model 4 report the empirical results. The coefficient of EID in Model 3 was positive but not significant, while the coefficient of EID in Model 4 was positively significant. The positive effects of innovation were not significant, and the disclosure of corporate environmental information in cities with low administrative levels actively promoted GI. The possible explanation is that cities with high administrative levels are generally also considered regional core cities. 
According to Friedman's core-periphery theory, core cities must have developed industries, concentrated capital, dense populations, and rapid economic growth, thus giving them the role of driving and affecting the periphery. In the development of cities as centers of economy, culture, transportation, education, and scientific research, China's core urban functions are evidently overloaded, and the problem of big city disease is more serious than in other places. This aspect is not sensitive to the signal transmission mechanism of the EID of high-level administrative city enterprises, which further affects GI activities.

\section{Conclusions}

\subsection{Discussion}

To understand the concept of sustainable development more in depth, this paper focuses on the relationship between EID and GI and explores the mechanism of EID's impact on corporate GI. Regarding the core variable EID, some previous studies used dummy variables to indicate the presence or absence of EID behavior and could not accurately measure the size of the EID level [84]. Some previous studies have also constructed an indicator system to try to quantitatively measure the EID level $[85,86]$, but as a result of environmental regulation policies and the types of disclosure about environmental information and other characteristics changing quickly, those index systems have become outdated. In this study, a new EID index system was constructed based on the recent practices in environmental regulation to quantitatively measure the EID level of enterprises. An empirical analysis was conducted using the data set of listed companies in China's heavily polluting industries from 2008 to 2019. The research results explain the relationship between EID and GI, which not only provides an empirical basis for China to improve the EID system of listed companies but also provides guidance for enterprises to achieve green and sustainable development. The results are as follows:

1) As a kind of voluntary environmental regulation, the effectiveness of EID on innovation is obviously insufficient. Previous studies mostly focused on the impact of command-and-control and market-incentive environmental regulation policies on innovation, including the work of some scholars in the study of the European carbon emissions trading system policy, and found that market-based instruments have no effect on GI [37], but the alternative view is that market-based tools have a more significant incentive effect on GI than command-and-control types [36]. Additionally, based on the negative binomial model and the least square model used to carry out the empirical analysis, we found that the type of EID, as a voluntary environmental regulation, significantly promoted the absolute and relative GI levels of enterprises, and when replacing the control, dependent, and independent variables, adding a city level for EID, and dividing EID into different growth types, the result was still robust.

2) After verifying that corporate EID has a positive role in promoting GI, this study used the intermediary model to conduct intermediary tests from three channels: government-level energy-saving innovation subsidies, social-level media attention, and corporate-level debt financing costs. The results found that the internal mechanism of corporate EID to promote GI mainly comes from the government-level energy-saving innovation subsidy effect and the social-level media attention effect, while failure of the corporate-level debt financing cost channel test may be due to the reduction in debt financing costs being not enough to affect the GI R\&D activities that require long-term substantial funding support.

3) From the perspective of the heterogeneity of two types of patents, EID promotes GI activities in enterprises regarding alternative energy production, energy conservation, and waste management, and it had the most obvious role in promoting energy conservation innovation. Moreover, compared with green patents for utility models, corporate EID had a greater role in promoting GI activities for invention patents. From the perspective of the heterogeneity of ownership by enterprises, state-owned enterprise EID was more conducive to GI activities than private enterprises. This may be because, in order to obtain more national resources, state-owned enterprises 
have lower operating efficiencies and market vitalities than private enterprises [87]. Support for state-owned enterprises will cause these enterprises to respond more actively to government policies and to disclose more environmental information. In terms of the heterogeneity of administrative levels in different cities, the positive effects of corporate EID in cities with high administrative levels on GI were not significant, while corporate EID in cities with low administrative levels significantly promoted GI.

\subsection{Implications}

The research on the GI effect of EID in this paper supplements existing research in the field and, at the same time, provides new ideas for taking into account the economic performance and environmental performance of enterprises. Based on the research results of this article, the following suggestions are made:

1) In view of the current situation of insufficient innovation drivers and environmental pollution in China, governments at all levels should spare no effort to implement innovation-driven development strategies. An effective innovative environmental policies at this stage through environmental information policies can encourage heavily polluting companies to implement GI development strategies, to unify economic and environmental benefits, and to provide an important guarantee for sustained and healthy development of a regional economy. Therefore, the government should adhere to the practice of combining market and administrative means, effectively implement EID policy, and introduce corresponding measures in combination with regions and enterprises, based on actual results. Companies should uphold the concept of sustainable development and green governance and should strengthen the reasonable construction of an internal EID system for companies.

2) As two important channels for EID to promote corporate GI, actively leveraging the power of government subsidies and social public opinion supervision is necessary. For enterprises that actively undertake social responsibilities and disclose high-quality environmental information, the government must commend, publicize, and provide material rewards. At the same time, in the process of supporting the GI of enterprises, a reasonable evaluation mechanism should be established to achieve transparent procedures and to prevent some enterprises from taking subsidy resources through rent-seeking activities. Public media should supervise the environmental performance and disclosure level of enterprises in real time and resolutely expose their environmental pollution and false information disclosure.

3) A differentiated EID supervision system should be developed. Blindly strengthening environmental regulations overall means not only high costs for government regulatory agencies but also lower regulatory efficiency. Therefore, in EID supervision, differentiated measures should be implemented for different types of enterprises. In order to accelerate the green transformation of enterprises, the EID system should focus on improving the quality of EID in areas with poor information disclosure to strengthen the supervision of information disclosure in this area, and on that basis strengthening the EID level of private enterprises and alleviating the overloaded state of functions in cities with high administrative levels. Sustainable economic development should also be achieved.

\subsection{Research Gaps and Direction of Further Studies}

First, this article discussed EID promoting corporate GI through the government's energy-saving innovation subsidy effect and the social media attention effect. However, the corporate-level debt financing cost effect has not passed the test and other internal channels may be ignored. Second, the research objects involved are listed companies in heavily polluting industries, and a large number of heavily polluting companies are still non-listed companies. Follow-up studies can specifically collect such data to test whether the relevant results are robust. Finally, the high-quality EID of enterprises leads to improvements in GI, 
but whether GI brings short-term or long-term economic benefits to enterprises remains to be clarified. The above problems need to be solved in our follow-up research.

Author Contributions: Conceptualization, D.H.; methodology, C.Z.; software, D.H.; validation, D.H.; formal analysis, D.H.; investigation, Y.H.; resources, D.H.; data curation, D.H. and Y.H.; writingoriginal draft preparation, D.H. and C.Z.; writing-review and editing, Y.H., C.Z.; visualization, D.H. and Y.H.; supervision, Y.H. and C.Z.; project administration, Y.H.; funding acquisition, C.Z. All authors have read and agreed to the published version of the manuscript.

Funding: This research was funded by the National Natural Science Foundation of China (No. 71704087), the National Natural Science Foundation of China (No. 71673182), the National Social Science Fund Project of China (No. 19BJY198).

Institutional Review Board Statement: Not applicable.

Informed Consent Statement: Not applicable.

Data Availability Statement: The data presented in this study are available on request from the corresponding author.

Conflicts of Interest: The authors declare no conflict of interest.

\section{References}

1. Mi, Z.; Zheng, J.; Meng, J.; Zheng, H.; Li, X.; Coffman, D.; Woltjer, J.; Wang, S.; Guan, D. Carbon emissions of cities from a consumption-based perspective. Appl. Energy 2019, 235, 509-518. [CrossRef]

2. Qu, S.; Wang, H.; Liang, S.; Shapiro, A.M.; Suh, S.; Sheldon, S.; Zik, O.; Fang, H.; Xu, M. A Quasi-Input-Output model to improve the estimation of emission factors for purchased electricity from interconnected grids. Appl. Energy 2017, 200, 249-259. [CrossRef]

3. Liu, C.; Ma, C.; Xie, R. Structural, Innovation and Efficiency Effects of Environmental Regulation: Evidence from China's Carbon Emissions Trading Pilot. Environ. Resour. Econ. 2020, 75, 741-768. [CrossRef]

4. $\quad$ Feng, Y.; Chen, H.; Chen, Z.; Wang, Y.; Wei, W. Has environmental information disclosure eased the economic inhibition of air pollution? J. Clean. Prod. 2021. [CrossRef]

5. Evans, M.F.; Gilpatric, S.M.; Liu, L. Regulation with direct benefits of information disclosure and imperfect monitoring. J. Environ. Econ. Manag. 2009, 57, 284-292. [CrossRef]

6. Zeng, S.X.; Xu, X.D.; Yin, H.T.; Tam, C.M. Factors that Drive Chinese Listed Companies in Voluntary Disclosure of Environmental Information. J. Bus. Ethics 2012, 109, 309-321. [CrossRef]

7. Beck, A.C.; Campbell, D.; Shrives, P.J. Content analysis in environmental reporting research: Enrichment and rehearsal of the method in a British-German context. Br. Account. Rev. 2010, 42, 207-222. [CrossRef]

8. Buallay, A. Is sustainability reporting (ESG) associated with performance? Evidence from the European banking sector. Manag. Environ. Qual. 2019, 30, 98-115. [CrossRef]

9. Guthrie, J.; Parker, L.D. Corporate Social Reporting: A Rebuttal of Legitimacy Theory. Account. Bus. Res. 1989, 19, 343-352. [CrossRef]

10. Kosajan, V.; Chang, M.; Xiong, X.; Feng, Y.; Wang, S. The design and application of a government environmental information disclosure index in China. J. Clean. Prod. 2018, 202, 1192-1201. [CrossRef]

11. Gray, R.; Kouhy, R.; Lavers, S. Simon Corporate social and environmental reporting: A review of the literature and a longitudinal study of UK disclosure. Account. Audit. Account. 1995. [CrossRef]

12. Cho, C.H.; Guidry, R.P.; Hageman, A.M.; Patten, D.M. Do actions speak louder than words? An empirical investigation of corporate environmental reputation. Account. Org. Soc. 2012, 37, 14-25. [CrossRef]

13. Zeng, S.X.; Xu, X.D.; Dong, Z.Y.; Tam, V.W.Y. Towards corporate environmental information disclosure: An empirical study in China. J. Clean. Prod. 2010, 18, 1142-1148. [CrossRef]

14. Santos, L.M.D.S.; Lucena, W.G.L.; Da Silva, W.V.; Bach, T.M.; Da Veiga, C.P. Explanatory Factors of the Environmental Disclosure of Potentially Polluting Companies: Evidence From Brazil. SAGE Open 2019. [CrossRef]

15. Liu, X.; Anbumozhi, V. Determinant factors of corporate environmental information disclosure: An empirical study of Chinese listed companies. J. Clean. Prod. 2009, 17, 593-600. [CrossRef]

16. Ioannou, I.; Serafeim, G. What drives corporate social performance? The role of nation-level institutions. J. Int. Bus. Stud. 2012, 43, 834-864. [CrossRef]

17. Khlif, H.; Guidara, A.; Souissi, M. Corporate social and environmental disclosure and corporate performance: Evidence from South Africa and Morocco. J. Account. Emerg. Econ. 2015, 5, 51-69. [CrossRef]

18. Wang, D.; Li, X.; Tian, S.; He, L.; Xu, Y.; Wang, X. Quantifying the dynamics between environmental information disclosure and firms' financial performance using functional data analysis. Sustain. Prod. Consum. 2021, 28, 192-205. [CrossRef]

19. Yang, Y.; Yao, C.; Li, Y. The impact of the amount of environmental information disclosure on financial performance: The moderating effect of corporate internationalization. Corp. Soc. Responsib. Environ. Manag. 2020, 27, 2893-2907. [CrossRef] 
20. Chang, Y.; Du, X.; Zeng, Q. Does environmental information disclosure mitigate corporate risk? Evidence from China. J. Contemp. Account. Econ. 2021, 17.

21. Doshi, A.R.; Dowell, G.W.S.; Toffel, M.W. How firms respond to mandatory information disclosure. Strateg. Manag. J. 2013, 34, 1209-1231. [CrossRef]

22. Liu, X.; Yu, Q.; Fujitsuka, T.; Liu, B.; Bi, J.; Shishime, T. Functional mechanisms of mandatory corporate environmental disclosure: An empirical study in China. J. Clean. Prod. 2010, 18, 823-832. [CrossRef]

23. Motoshita, M.; Sakagami, M.; Kudoh, Y.; Tahara, K.; Inaba, A. Potential impacts of information disclosure designed to motivate Japanese consumers to reduce carbon dioxide emissions on choice of shopping method for daily foods and drinks. J. Clean. Prod. 2015, 101, 205-214. [CrossRef]

24. Lu, J.; Li, H. The impact of government environmental information disclosure on enterprise location choices: Heterogeneity and threshold effect test. J. Clean. Prod. 2020. [CrossRef]

25. Cailou, J.; Fuyu, Z.; Chong, W. Environmental information disclosure, political connections and innovation in high-polluting enterprises. Sci. Total Environ. 2021. [CrossRef]

26. Barbera, A.J.; McConnell, V.D. The impact of environmental regulations on industry productivity: Direct and indirect effects. J. Environ. Econ. Manag. 1990, 18, 50-65. [CrossRef]

27. Gray, W.B.; Shadbegian, R.J. Plant vintage, technology, and environmental regulation. J. Environ. Econ. Manag. 2003, 46, 384-402. [CrossRef]

28. Porter, M.E.; Van der Linde, C. Toward a new conception of the environment-competitiveness relationship. J. Econ. Perspect. 1995, 9, 97-118. [CrossRef]

29. Acemoglu, D. Directed Technical Change. Rev. Econ. Stud. 2002, 4, 781-809. [CrossRef]

30. Kihombo, S.; Ahmed, Z.; Chen, S.; Adebayo, T.S.; Kirikkaleli, D. Linking financial development, economic growth, and ecological footprint: What is the role of technological innovation? Environ. Sci. Pollut. Res. 2021. [CrossRef] [PubMed]

31. Umar, M.; Ji, X.; Kirikkaleli, D.; Shahbaz, M.; Zhou, X. Environmental cost of natural resources utilization and economic growth: Can China shift some burden through globalization for sustainable development? Sustain. Dev. 2020, 28, 1678-1688. [CrossRef]

32. Adebayo, T.S.; Kirikkaleli, D. Impact of renewable energy consumption, globalization, and technological innovation on environmental degradation in Japan: Application of wavelet tools. Environ. Dev. Sustain. 2021. [CrossRef]

33. Rhodes, E.; Wield, D. Implementing New Technologies: Innovation and the Management of Technology; Wiley Blackwell: Hoboken, NJ, USA, 1994.

34. Braun, E.; Wield, D. Regulation as a means for the social control of technology. Technol. Anal. Strateg. 1994, 6, 259-272. [CrossRef]

35. Song, W.; Yu, H. Green innovation Strategy and Green innovation: The Roles of Green Creativity and Green Organizational Identity. Corp. Soc. Responsib. Environ. Manag. 2018, 25, 135-150. [CrossRef]

36. DeShazo, J.R.; Sheldon, T.L.; Carson, R.T. Designing policy incentives for cleaner technologies: Lessons from California's plug-in electric vehicle rebate program. J. Environ. Econ. Manag. 2017, 84, 18-43. [CrossRef]

37. Calel, R.; Dechezleprêtre, A. Environmental Policy and Directed Technological Change: Evidence from the European Carbon Market. Rev. Econ. Stat. 2014, 98, 173-191. [CrossRef]

38. Cai, X.; Zhu, B.; Zhang, H.; Li, L.; Xie, M. Can direct environmental regulation promote green technology innovation in heavily polluting industries? Evidence from Chinese listed companies. Sci. Total Environ. 2020. [CrossRef]

39. Chen, X.; Li, W.; Chen, Z.; Huang, J. Environmental regulation and real earnings management_Evidence from the SO2 emissions trading system in China. Financ. Res. Lett. 2021. [CrossRef]

40. Geng, Y.; Liu, W.; Li, K.; Chen, H. Environmental regulation and corporate tax avoidance: A quasi-natural experiment based on the eleventh Five-Year Plan in China. Energy Econ. 2021. [CrossRef]

41. Hummel, K.; Schlick, C. The relationship between sustainability performance and sustainability disclosure - Reconciling voluntary disclosure theory and legitimacy theory. J. Account. Public Policy 2016, 35, 455-476. [CrossRef]

42. Endres, A.; Friehe, T.; Rundshagen, B. Environmental liability law and R\&D subsidies: Results on the screening of firms and the use of uniform policy. Environ. Econ. Policy Stud. 2015, 17, 521-541.

43. Jacoby, G.; Liu, M.; Wang, Y.; Wu, Z.; Zhang, Y. Corporate governance, external control, and environmental information transparency: Evidence from emerging markets. J. Int. Financ. Mark. Inst. Money 2019, 58, 269-283. [CrossRef]

44. Lee, E.; Walker, M.; Zeng, C.C. Do Chinese state subsidies affect voluntary corporate social responsibility disclosure? J. Account. Public Policy 2017, 36, 179-200. [CrossRef]

45. Albrizio, S.; Kozluk, T.; Zipperer, V. Environmental policies and productivity growth: Evidence across industries and firms. J. Environ. Econ. Manag. 2017, 81, 209-226. [CrossRef]

46. Bhandari, A.; Javakhadze, D. Corporate social responsibility and capital allocation efficiency. J. Corp. Financ. 2017, 43, 354-377. [CrossRef]

47. Lu, Y.; Wang, Y.; Zuo, J.; Jiang, H.; Huang, D.; Rameezdeen, R. Characteristics of public concern on haze in China and its relationship with air quality in urban areas. Sci. Total Environ. 2018. [CrossRef] [PubMed]

48. Lyon, T.P.; Maxwell, J.W. Greenwash: Corporate Environmental Disclosure under Threat of Audit. J. Econ. Manag. Strategy 2011, 20,3-41. [CrossRef]

49. Huang, R.; Chen, D. Does Environmental Information Disclosure Benefit Waste Discharge Reduction? Evidence from China. J. Bus. Ethics 2015, 129, 535-552. [CrossRef] 
50. Epstein, M.J.; Freedman, M. Social Disclosure and the Individual Investor. Account. Audit. Account. J. 1994, 7, 94-109. [CrossRef]

51. Dhaliwal, D.S.; Li, O.Z.; Tsang, A.; Yang, Y.G. Voluntary Nonfinancial Disclosure and the Cost of Equity Capital: The Initiation of Corporate Social Responsibility Reporting. Account. Rev. 2011, 86, 59-100. [CrossRef]

52. Flammer, C. Corporate Social Responsibility and Shareholder Reaction: The Environmental Awareness of Investors. Acad. Manag. J. 2013, 56, 758-781. [CrossRef]

53. Chan, R.Y.K.; Lau, L.B.Y. Antecedents of green purchases: A survey in China. J. Consum. Mark. 2000, 17, 338-357. [CrossRef]

54. Dibrell, C.; Craig, J.B.; Hansen, E.N. How managerial attitudes toward the natural environment affect market orientation and innovation. J. Bus. Res. 2011, 64, 401-407. [CrossRef]

55. Menguc, B.; Auh, S.; Ozanne, L. The Interactive Effect of Internal and External Factors on a Proactive Environmental Strategy and its Influence on a Firm's Performance. J. Bus. Ethics 2010, 94, 279-298. [CrossRef]

56. Manso, G. Motivating Innovation. J. Financ. 2011, 66, 1823-1860. [CrossRef]

57. Montmartin, B.; Herrera, M. Internal and external effects of R\&D subsidies and fiscal incentives: Empirical evidence using spatial dynamic panel models. Res. Policy 2015, 44, 1065-1079.

58. Stiglitz, J.E. Leaders and followers: Perspectives on the Nordic model and the economics of innovation. J. Public Econ. 2015, 127, 3-16. [CrossRef]

59. Peress, J.; Fang, L. Media Coverage and the Cross-Section of Stock Returns. J. Financ. 2008, 64, 2023-2052.

60. Strycharz, J.; Strauss, N.; Trilling, D. The Role of Media Coverage in Explaining Stock Market Fluctuations: Insights for Strategic Financial Communication. Int. J. Strategy Commun. 2017, 12, 1-19. [CrossRef]

61. Mullainathan, S.; Shleifer, A. The Market for News. Am. Econ. Rev. 2005, 95, 1031-1053. [CrossRef]

62. Howitt, P.; Aghion, P. A Model of Growth Through Creative Destruction. Econometrica 1992, 60, 323-351.

63. Ren, S.; Wei, W.; Sun, H.; Xu, Q.; Hu, Y.; Chen, X. Can mandatory environmental information disclosure achieve a win-win for a firm's environmental and economic performance? J. Clean. Prod. 2020. [CrossRef]

64. Goss, A.; Roberts, G.S. The impact of corporate social responsibility on the cost of bank loans. J. Bank. Financ. 2011, 35, 1794-1810. [CrossRef]

65. Zhao, X.; Zhang, L.; Song, Y. Environmental Information Disclosure of Listed Company Study on the Cost of Debt Capital Empirical Data: Based on Thermal Power Industry. Can. Soc. Sci. 2014, 6, 88-94.

66. Lindman, Å.; Söderholm, P. Wind energy and green economy in Europe: Measuring policy-induced innovation using patent data. Appl. Energy 2016, 179, 1351-1359. [CrossRef]

67. Tan, Y.; Tian, X.; Zhang, X.; Zhao, H. The real effect of partial privatization on corporate innovation: Evidence from China's split share structure reform. J. Corp. Financ. 2020, 64, 101661. [CrossRef]

68. Popp, D. Induced Innovation and Energy Prices. Am. Econ. Rev. 2002, 92, 160-180. [CrossRef]

69. Popp, D. International innovation and diffusion of air pollution control technologies: The effects of NOX and SO2 regulation in the US, Japan, and Germany. J. Environ. Econ. Manag. 2006, 51, 46-71. [CrossRef]

70. Clarkson, P.M.; Li, Y.; Richardson, G.D.; Vasvari, F.P. Revisiting the relation between environmental performance and environmental disclosure: An empirical analysis. Account. Organ. Soc. 2008, 33, 303-327. [CrossRef]

71. Katmon, N.; Mohamad, Z.Z.; Norwani, N.M.; Farooque, O.A. Comprehensive Board Diversity and Quality of Corporate Social Responsibility Disclosure: Evidence from an Emerging Market. J. Bus. Ethics 2019, 157, 447-481. [CrossRef]

72. Orlitzky, M. Does Firm Size Comfound the Relationship Between Corporate Social Performance and Firm Financial Performance? J. Bus. Ethics 2001, 33, 167-180. [CrossRef]

73. Zhang, J.; Chen, Z.; Yang, L.; Xin, F. On Evaluating China's Innovation Subsidy Policy: Theory and Evidence. Econ. Res. J. 2015, 50, 4-17. (In Chinese)

74. Barron, D.N.; West, E.; Hannan, M.T. A Time to Grow and a Time to Die: Growth and Mortality of Credit Unions in New York City, 1914-1990. Am. J. Sociol. 1994, 100, 381-421. [CrossRef]

75. Ziedonis, R.H. Don't Fence Me In: Fragmented Markets for Technology and the Patent Acquisition Strategies of Firms. Manag. Sci. 2004, 50, 804-820. [CrossRef]

76. Yuan, L.; Pangarkar, N.; Wu, J. The interactive effect of time and host country location on Chinese MNCs' performance: An empirical investigation. J. World Bus. 2016, 51, 331-342. [CrossRef]

77. Lu, J.W.; Beamish, P.W. International Diversification and Firm Performance: The S-curve Hypothesis. Acad. Manag. J. 2004, 47, 598-609.

78. Pittman, J.A.; Fortin, S. Auditor choice and the cost of debt capital for newly public firms. J. Account. Econ. 2004, 37, 113-136. [CrossRef]

79. Minnis, M. The Value of Financial Statement Verification in Debt Financing: Evidence from Private, U.S. Firms. J. Account. Res. 2011, 49, 457-506. [CrossRef]

80. Cameron, A.; Trivedi, P. Regression Analysis of Count Data; Cambridge University Press: Cambridge, UK, 1998.

81. Baron, R.M.; Kenny, D.A. The moderator-mediator variable distinction in social psychological research: Conceptual, strategic, and statistical considerations. J. Pers. Soc. Psychol. 1986, 51, 1173-1182. [CrossRef]

82. Wen, Z.; Ye, B. Analyses of Mediating Effects: The Development of Methods and Models. Adv. Psychol. Sci. 2014, 22, 731-745. (In Chinese) [CrossRef] 
83. Zhang, J.; Gao, D.; Xia, Y. Do Patents Drive Economic Growth in China-An Explanation Based on Government Patent Subsidy Policy. China Ind. Econ. 2016, 1, 83-98. (In Chinese)

84. Fang, J.; Liu, C.; Gao, C. The impact of environmental regulation on firm exports: Evidence from environmental information disclosure policy in China. Environ. Sci. Pollut. Res. 2019, 26, 37101-37113. [CrossRef]

85. Meng, X.H.; Zeng, S.X.; Tam, C.M. From Voluntarism to Regulation: A Study on Ownership, Economic Performance and Corporate Environmental Information Disclosure in China. J. Bus. Ethics 2013, 116, 217-232. [CrossRef]

86. Fonseka, M.; Rajapakse, T.; Richardson, G. The effect of environmental information disclosure and energy product type on the cost of debt: Evidence from energy firms in China. Pac.-Basin. Financ. J. 2019, 54, 159-182. [CrossRef]

87. Li, Y.; Yang, R. Does Reliance on SOEs Hamper the Improvement of Resource Allocation Efficiency? Econ. Res. J. 2018, 53, 80-94. (In Chinese) 